\title{
Adenovirus entry into cells, a quantitative fluorescence microscopy approach
}

\author{
Urs F. Greber, Michel Nakano \& Maarit Suomalainen \\ Institute of Zoology \\ University of Zurich \\ Winterthurerstrasse 190 \\ CH-8057 Zurich \\ Switzerland
}

Fax: (41) 16356822

Tel: (41) 16354841

ufgreber@zool.unizh.ch

Running head: Quantitative entry of fluorescent adenovirus

\section{INTRODUCTION}

Adenoviruses carry their DNA genome into post-mitotic nuclei of a variety of human cells, either within an organism (in vivo) or outside an organism in culture (ex vivo) (1). Recombinant adenoviruses are developed in many laboratories as gene delivery vehicles to treat hereditary and acquired human disorders of somatic cells $(2 ; 3)$. Diseased lungs of cystic fibrosis patients have been pioneered for treatment with recombinant adenovirus vectors (4). Preliminary results are promising, but demonstrate that the disease has not yet been cured by the emerging gene transfer technology (5). One reason for limited success was that the transgenes were not expressed adequately in the diseased tissues, either due to low efficiency of virus delivery to the target cell or inefficient DNA import into the nucleus. In this chapter, we describe a quantitative method to determine transport of fluorescently labeled wild type adenovirus 2 to the nucleus of a model cell line, HeLa cells. This protocol should be directly applicable to recombinant adenoviruses in a variety of cell lines, including peripheral blood cells, fibroblasts, polarized epithelial cells and differentiated neurons.

\subsection{Adenovirus structure}

Adenoviruses contain at least 11 different polypeptides (6). A hierarchically organized network of interactions between capsid proteins encloses a linear double-stranded DNA genome of about $34 \mathrm{~kb}$, 
which is linked to the capsid via the internal protein VI (7). Individual building blocks of the major capsid protein hexon join with minor elements, such as the facet-stabilizing protein IIIa and the hexoncementing protein IX, as well as the vertex proteins penton base and protruding fiber. Inside the nucleus of an infected cell, adenovirus DNA is packaged into the capsid together with condensing proteins V, VII and $\mu$ and cysteine protease L3/p23.

\subsection{Internalization and penetration}

Adenovirus type 2 uses a stepwise cell entry program (8). Its fibers attach to an epithelial cell surface receptor of the immunoglobulin gene family (9-11). In the case of hematopoietic cells, an alpha $\mathrm{b}_{\mathrm{m}} \mathrm{beta}_{2}$ integrin has also been reported as a high affinity receptor attaching to the virus penton base protein (12). In epithelial cells, fibers are shed from the particle and virus enters by receptor-mediated endocytosis via fibronectin-binding $\alpha_{\mathrm{V}} \beta_{5}$ integrins binding to penton base $(13 ; 14)$. After $10 \mathrm{~min}$ of internalization, most virus particles are found within endosomes. Penetration of individual virions across the endosomal membrane is facilitated by slightly acidic $\mathrm{pH}$ and appears to require binding of penton base to the $\alpha_{V} B_{5}$ integrin $(15 ; 16)$. When added to cells in high amounts virions can also get into the cytoplasm in the absence of acidified endosomes (14). In the cytoplasm, the internal capsid protein VI is degraded by the reactivated viral protease and protein IX is dissociated from the capsid. Protease is reactivated by two signals, penton base binding to integrin receptors at the plasma membrane and the reducing cytoplasmic milieu. These triggers prepare the capsid for disassembly near the nuclear membrane (17).

\subsection{Nuclear transport}

All the proteins needed for virus assembly must enter the nucleus after synthesis in the cytoplasm. They either directly or indirectly contain nuclear targeting information, such as nuclear localization sequences (NLSs) (for review of nuclear import of proteins, see 18). It is possible that NLSs present on capsid protein(s) are involved in nuclear targeting of incoming virus particles. In addition, mechanical forces, generated by cytoplasmic motor proteins, may be required for virus localization to the nucleus. In any case, structurally altered adenoviruses reach the nuclear membrane and attach to the cytoplasmic side of the nuclear pore complex (14). Nuclear import of the DNA and associated proteins, such as protein VII, then occurs after DNA is dissociated from the capsid (17). 


\section{MATERIALS}

Commonly used chemicals were from Sigma or Fluka. All stock solutions were made up in double distilled water and filtered through $0.2 \mu$ m polyether sulfon membrane filters (Semadeni, Switzerland). Working solutions were diluted into double distilled water before use.

\subsection{Cell growth and virus purification}

\subsubsection{Cells and Chemicals}

Cells for virus growth are available from American Type Culture Collection (ATCC), e.g., HeLa cells (cervical epithelioid carcinoma), HeLa S3 cells (cervical epithelioid carcinoma), KB cells (nasopharyngal carcinoma), 293 cells (transformed embryonal kidney cells) and A549 cells (human lung carcinoma).

$100 \mathrm{~mm}$ dishes (Costar, cell culture grade, $78.5 \mathrm{~cm}^{2}$ ). Dulbecco's modified Eagle's medium (GibcoBRL, DMEM) containing 7\% Clone III serum (Hyclone), $1 \%$ non-essential amino acids, $1 \%$ glutamine and 100 units $/ \mathrm{ml}$ streptomycin, $0.1 \mathrm{mg} / \mathrm{ml}$ penicillin (all from Gibco-BRL). Bovine serum albumin (BSA, Sigma, A-9418: 10\% (w/v) filtered through $0.2 \mu \mathrm{m}$ membrane). DMEM containing 0.2\% BSA. $10 \%$ sodium dodecyl sulfate (SDS, molecular biology grade).

1 x phosphate buffered saline (PBS), prepared from a premixed salt stock (Gibco-BRL). $1 \mathrm{M}$ Tris-HCl, pH 8.1. $5 \mathrm{M} \mathrm{NaCl} .1 \mathrm{M} \mathrm{MgCl}_{2}$. 22.4\% (w/w) cesium chloride ( $\mathrm{CsCl}$, ultrapure grade): dissolve $60 \mathrm{~g}$ in $0.05 \mathrm{M}$ Tris- $\mathrm{HCl}$, pH 8 yielding a total of $267.8 \mathrm{~g} .42 .2 \%(\mathrm{w} / \mathrm{w}) \mathrm{CsCl}$ : dissolve $72.5 \mathrm{~g}$ in $0.05 \mathrm{M}$ Tris- $\mathrm{HCl}, \mathrm{pH} 8$ yielding a total of $171.8 \mathrm{~g}$. Immediately before use, prepare $\mathrm{CsCl}$ step gradient for SW 55 rotor: $1.5 \mathrm{ml}$ of $22.4 \%$ solution over $1.5 \mathrm{ml}$ of $42.2 \%$ solution. Freon (1,1,2-Trichloro-1,2,2- 
Trifluoroethane, sds, France), saturated with 1/3 vol of 0.01 M Tris-HCL, pH 8.0. 0.2 M Phenylmethyl-sulfonyl fluoride (PMSF): $34 \mathrm{mg} / \mathrm{ml}$ in ethanol. This solution is stable at $-20^{\circ} \mathrm{C}$ for a few days. Glycerol (autoclaved). 2\% (w/v) uranyl-acetate. 2\% (w/v) silicotungstic acid, pH 7 adjusted with $1 \mathrm{~N}$ $\mathrm{KOH}$.

\subsubsection{Hardware}

Cell incubator, equilibrated to $5 \%$ humidified $\mathrm{CO}_{2}$ atmosphere at $37^{\circ} \mathrm{C}$. Rocking plate fitting into incubator. Ultracentrifuge, SW 55 (or SW 50.1) rotor and corresponding ultra clear thermoplastic tubes (Beckman). Table top centrifuge (Heraeus). Low speed centrifuge holding 50 and $15 \mathrm{ml}$ screw capped plastic tubes. Pasteur pipettes, autoclaved. Vacuum dialysis apparatus with fitting $75 \mathrm{kD}$ collodion membrane bag (Schleicher \& Schuell). $0.45 \mu \mathrm{m}$ sterile filters (Millex-GS filter, Millipore). $50 \mathrm{ml}$ and $15 \mathrm{ml}$ screw capped plastic centrifuge tubes. Spectrophotometer including quartz cuvette (e.g., Pharmacia Ultrospec 2000) for measurements at 260 and $280 \mathrm{~nm}$. Transmission electron microscope (e.g., Zeiss EM 902A at acceleration voltage of 80’000) and pallodium film and carbon-coated EM grids (SYNAP TEK G-2793, Plano, Germany). Sodium dodecyl sulfate polyacrylamide gel electrophoresis system (SDS-PAGE, Hoefer).

\subsection{Plaque assay}

A549 (human lung carcinoma) cells grown in $30 \mathrm{~mm}$ plastic dishes (Costar) as described in sections 2.1. and 3.1.. $5 \mathrm{x}$ concentrated DMEM (made up from powder and stored at $4^{\circ} \mathrm{C}$ for less than 2 months protectred from light, Gibco-BRL). BSA (Sigma, A-9418). $100 \mathrm{ml}$ glass flask, autoclaved, $500 \mathrm{ml}$ of $\mathrm{ddH}_{2} \mathrm{O}$, autoclaved. 1 x phosphate buffered saline (PBS), prepared from a premixed salt stock (GibcoBRL). $37 \%$ formaldehyde: for working solution, dilute $10 \mathrm{x}$ into $100 \mathrm{ml} 1 \mathrm{x}$ PBS. To prepare $100 \mathrm{ml}$ of $1 \mathrm{x}$ maintenance medium, mix $20 \mathrm{ml}$ of 5 x DMEM, $10 \mathrm{ml}$ Tryptose Phosphate Broth (Gibco-BRL), 
$9 \mathrm{ml}$ sodium bicarbonate (2.25 g/100 ml, Gibco-BRL), $2 \mathrm{ml}$ Clone III serum (Hyclone), $2 \mathrm{ml} 1 \mathrm{M}$ $\mathrm{MgCl}_{2}, 1 \mathrm{ml}$ penicillin/streptomycin (10’000 units/10 mg per ml, Gibco-BRL), $2 \mathrm{ml}$ L-glutamine (100 $\mathrm{x}$, Gibco-BRL) and $\mathrm{ddH}_{2} \mathrm{O}$ to $80 \mathrm{ml}$. This solution can be filtered through a $0.2 \mu \mathrm{m}$ membrane and kept light protected in the cold for about 4 weeks. To prepare $100 \mathrm{ml}$ of overlay agar medium, microwave $0.625 \mathrm{~g}$ agarose (sea plaque, low gelling, FMC) in a screw capped glass flask containing $20 \mathrm{ml}$ of $\mathrm{ddH}_{2} \mathrm{O}$, until agar is completely dissolved (no sign of Schlieren). Equilibrate in $37^{\circ} \mathrm{C}$ water bath for about 1-2 hours and add to $80 \mathrm{ml}$ of prewarmed maintenance medium. Mix well avoiding air bubbles and add immediately over cells. Cristal Violet: to obtain a $50 \mathrm{x}$ stock solution, dissolve $0.25 \mathrm{~g}$ of cristal violet (Sigma) in $5 \mathrm{ml}$ of ethanol. For working solution dilute into $\mathrm{ddH}_{2} \mathrm{O}$.

\subsection{Fluorescent virus entry}

\subsubsection{Chemicals and cells}

Micro BCA assay for protein determination (Pierce). $\mathrm{CsCl}$ purified adenovirus. Virus dialysis buffer consisting of $0.1 \mathrm{M}$ sodium bicarbonate, $0.05 \mathrm{M}$ sodium chloride, $1 \mathrm{mM} \mathrm{MgCl} 2 \mathrm{pH}$ 8.2. Collodion membrane (75 kD cut off) and dialysis apparatus (Schleicher \& Schuell). Texas-red-X (dissolved at 5 $\mathrm{mg} / \mathrm{ml}$ in water-free DMSO, Molecular Probes). Freshly made $1.5 \mathrm{M}$ hydroxylamine $\mathrm{pH}$ 8.5.

Cells grown on glass coverslips in DMEM-clone III serum placed in 24 well dish (Costar) in a humidified $37^{\circ} \mathrm{C} \mathrm{CO}_{2}$ incubator. Virus binding medium: RPMI-0.2\% BSA containing $15 \mathrm{mM}$ Hepes, $\mathrm{pH}$ is adjusted to 7.4 with concentrated $\mathrm{NaOH}$. Virus internalization medium: DMEM- $0.2 \%$ BSA. PBS. 3.3\% para-formaldehyde made up in PBS according to standard procedures (19). $0.5 \mathrm{M}$ ammonium chloride (NH4Cl). PBS containing 2\% 1,4,-Diazabicyclo[2,2,2]octane (DABCO). Nailpolish. 


\subsubsection{Hardware}

Round glass coverslips (12 mm diameter, Assistent, Winiger, Switzerland) are washed in $1 \mathrm{~N}$ hydrochloric acid for $10 \mathrm{~min}(\mathrm{HCl})$, followed by three changes in $\mathrm{ddH}_{2} \mathrm{O}$, methanol and again $\mathrm{ddH}_{2} \mathrm{O}$. They are placed between 2 filter papers in a glass petri dish, autoclaved and dried in an oven at $60^{\circ} \mathrm{C}$. Aluminium plate. Ice bucket. Wipping rocker kept at $4^{\circ} \mathrm{C}$. Reichert-Jung Polyvar microscope (Merck, Switzerland) equipped with a $40 \mathrm{x}$ oil immersion objective (numerical aperature 1.0), Nomarski differential interference optics (DIC) and a texas red filter set (excitation filter 530 to 585 nm, emission filter LP 615) linked to a Charge Coupled Device (CCD) video camera (Hamamatsu C5405, Hamamatsu Photonics, Germany). Macintosh computer on-line to the camera system loaded with Argus-20 imaging acquisition program (Hamamatsu Photonics, Germany) and Photoshop Version 3.05 (Adobe). NIH image analysis software (version 1.6): World Wide Web at http://rsb.info.nih.gov/nih-image/. 


\section{METHODS}

\subsection{Adenovirus purification}

The following protocol was modified according to (20).

\subsubsection{Procedure}

1. Grow KB cells on ten $100 \mathrm{~mm}$ tissue culture dishes in DMEM containing 7\% Clone III serum to $90 \%$ confluency corresponding to about $8 \times 10^{7}$ cells.

2. Infect cells with 1 to 5 plaque forming units per cell in $3 \mathrm{ml}$ of DMEM-BSA on a rocking platform at $37^{\circ} \mathrm{C}$ in a $\mathrm{CO}_{2}$ incubator for $90 \mathrm{~min}$.

3. Remove inoculum, add $7 \mathrm{ml}$ of DMEM-7\% Clone III serum and incubate in $\mathrm{CO}_{2}$ incubator at $37^{\circ} \mathrm{C}$ until cytopathic effect (CPE) occurs about 3 days later. Make sure CPE is complete and cells are detached from the dish.

4. Collect cells with a short Pasteur pipette and transfer to $50 \mathrm{ml}$ screw capped centrifuge tube. Pellet cells at $600 \mathrm{x}$ g for $10 \mathrm{~min}$. Wash pellet in $10 \mathrm{ml}$ of PBS and transfer suspension to $15 \mathrm{ml}$ centrifuge tube. Pellet cells.

5. Resuspend cells in $0.01 \mathrm{M}$ Tris- $\mathrm{HCl}, \mathrm{pH} 8.1,0.5 \mathrm{mM}$ PMSF at $2 \times 10^{7}$ cells/ml and freeze-thaw 3 times in liquid nitrogen and a $37^{\circ} \mathrm{C}$ water bath. At this point, the preparation can be kept frozen at $-70^{\circ}$ C for several months. 
6. Extract cells with an equal volume of Freon by gently vortexing and shaking by hand for 1 to 2 min. The suspension should become viscous and homogenous. Separate organic and aqueous phase by centrifugation at $1000 \mathrm{x} \mathrm{g}$ for $5 \mathrm{~min}$ at $4^{\circ} \mathrm{C}$ and collect upper aqueous phase.

6 a. To prepare stock virus, filter-sterilize aqueous phase through $0.45 \mu \mathrm{m}$ disk filter and shock freeze aliquots in liquid nitrogen. Store at $-70^{\circ} \mathrm{C}$.

7. Layer upper aqueous phase on top of a $\mathrm{CsCl}$ step gradient and spin for 2 hours at $32^{\prime} 000 \mathrm{rpm}$ in SW55 rotor at $4^{\circ} \mathrm{C}$.

8. Collect virus band by carefully removing liquid from the top using a Pasteur pipette. Dilute virus (approximately $400 \mu \mathrm{l}$ ) with $0.01 \mathrm{M}$ Tris- $\mathrm{HCl}, \mathrm{pH} 8.1$ to $2 \mathrm{ml}$ and overlay over a second $\mathrm{CsCl}$ step gradient as described in step 7. Spin isopycnically for 18 hours at $32^{\prime} 000 \mathrm{rpm}$ at $4^{\circ} \mathrm{C}$.

9. Collect virus band as described in step 8 .

10. Vacuum-concentrate virus in collodion membrane by dialysis against $0.01 \mathrm{M}$ Tris- $\mathrm{HCl}, \mathrm{pH} 8.1$, $0.15 \mathrm{M} \mathrm{NaCl}, 1 \mathrm{mM} \mathrm{MgCl}$. Observe approximately every $5 \mathrm{~min}$ and concentrate to 1 to $2 \mathrm{mg} / \mathrm{ml}$ (about 100 to $200 \mu \mathrm{l}$ ). Disconnect vacuum and continue dialysis for another 2 to 3 hours on ice. Change buffers at least twice. Use virus immediately or add glycerol to $10 \%$ and shock-freeze aliquots in liquid nitrogen. Store at $-70^{\circ} \mathrm{C}$ up to several months. 


\subsubsection{Quality control}

\subsubsection{Optical measurements}

The amount of optical particle units is determined by the absorbance of dissociated virus at $260 \mathrm{~nm}$.

1. Dissolve a small aliquot of virus in $0.5 \%$ SDS, $0.02 \mathrm{M}$ Tris- $\mathrm{HCl}, \mathrm{pH} 7.4$ at $37^{\circ} \mathrm{C}$ for 15 min with occasional shaking.

2. Place disrupted virus into quartz cuvette and measure absorbances at $260 \mathrm{~nm}$ (OD260) and $280 \mathrm{~nm}$.

3. Determine virus concentration by multiplying OD260 value with the dilution factor and dividing by the extinction coefficient $\left(\mathrm{E}=9 \times 10^{-13} \mathrm{OD} \mathrm{ml} \mathrm{cm} \mathrm{virus}{ }^{-1}\right)$ as determined for adenovirus type $5(21)$. Optically pure virus should have an absorbance ratio $260 / 280$ of 1.33 to 1.45 (22). 1 OD260 unit equals $1.1 \times 10^{12}$ optical virus particles, based on the measurement that $13 \%$ of the virus dry weight is accounted for by DNA (23). 1 OD260 is equivalent to about $1.2 \mathrm{mg} / \mathrm{ml}$ protein. This value roughly corresponds to the amount of protein $(0.8 \mathrm{mg} / \mathrm{ml})$, determined in our Micro BCA protein assay (Pierce).

\subsubsection{Plaque assay}

Plaque assays determine the biological activity of a virus preparation. They are the most stringent criterium for virus functionality. Results are expressed as plaque forming units (PFU).

1. Seed A549 cells $48 \mathrm{~h}$ prior to infection into $30 \mathrm{~mm}$ plastic dishes and grow to about $95 \%$ confluency. Set up enough dishes to perform test in duplicates including 2 dishes as non-infected controls. 
Adenovirus methods and protocols, in Meth. Mol. Med. Vol 21, 217-230, Humana Press, Inc, ed Wold, W.S.M.

2. Prepare 10-fold serial dilutions of virus into $2 \mathrm{ml}$ of DMEM-BSA, typically ranging from $10^{-5}$ to $10^{-9}$.

3. Remove medium from the cells, wash cells once with DMEM-BSA and add $0.5 \mathrm{ml}$ of diluted virus. Incubate on a gently rocking plate in a humidified $\mathrm{CO}_{2}$ incubator @ $37^{\circ} \mathrm{C}$ for $90 \mathrm{~min}$.

4. Suck off inoculum and add $2 \mathrm{ml}$ of overlay agar medium. Let agar solidify in the cold for $10 \mathrm{~min}$ and place dishes into humidified $\mathrm{CO}_{2}$ incubator @ $37^{\circ} \mathrm{C}$ for 2 to 3 days.

5. Overlay with an additional $2 \mathrm{ml}$ of overlay agar medium and incubate for another 3 to 4 days @ $37^{\circ}$

$\mathrm{C}$ as above. Examine plaque formation by eye against a dark surface beginning at day 5 after infection.

6. When no more new plaques grow (e.g., at day 7), determine the number of plaques by staining cells with cristal violet. Carefully remove agar with a spatula (avoid scratching the cells). Fix cells in $3.7 \%$ formaldehyde-PBS for $10 \mathrm{~min}$ and stain cells with cristal violet for $5 \mathrm{~min}$. Suck off solution and count plaques.

\subsubsection{Electron microscopy and negative staining}

To determine if isolated adenovirus is free of other virus particles, such as adeno-associated virus (AAV), the following procedure can be applied. All steps are carried out at room temperature.

1. Spot $5 \mu \mathrm{l}$ of a 1:10 dilution (into $0.01 \mathrm{M}$ Tris-HCl, $\mathrm{pH}$ 8) of stock virus onto a piece of parafilm foil.

2. Place a carbon coated plastified EM grid (glow discharged) upside down on virus droplet and absorb virus to the grid for $2 \mathrm{~min}$. 
3. Pick up grid with a pair of fine tweezers and remove excess liquid with a piece of Whatman filter paper.

4. Place grid upside-down on $5 \mu \mathrm{l}$ of $2 \%$ uranyl-acetate and incubate for $20 \mathrm{sec}$. Alternatively, stain virus with $2 \%$ silicotungstic acid (made up in ddH2O, pH adjusted with $1 \mathrm{~N} \mathrm{KOH}$ to 7 ) for 10 sec.

5. Blot off excess stain with filter paper and dry specimen for 1 hour.

6. Observe sample in the transmission electron microscope at $80 \mathrm{kV}$ and $80^{\prime} 000$ to 200 ' 000 fold magnification.

\subsubsection{SDS-PAGE}

Virus homogeneity can also be tested by SDS-polyacrylamide gel electrophoresis (SDS-PAGE) followed by Coomassie blue staining, e.g., as described $(8 ; 24)$. Pure adenovirus is characterized by a predominant hexon band, proteins V and VII and fainter bands representing penton base, fiber, IIIa, VI, and IX (Fig. 1, lane 1).

\subsection{Quantitative subcellular analysis of incoming fluorescent virus}

\subsubsection{Texas-red and FITC labeling of adenovirus}

1. Dialyse purified adenovirus against $0.1 \mathrm{M}$ sodium bicarbonate, $0.05 \mathrm{M}$ sodium chloride, $1 \mathrm{mM}$ $\mathrm{MgCl}_{2} \mathrm{pH} 8.2$ using a $75 \mathrm{kD}$ cut off collodion membrane as described in section 3.1.1., step 10 . 
2. Determine protein concentration using the Micro BCA assay according to the manufacturer's conditions (Pierce).

3. To $0.4 \mathrm{ml}$ of $0.8 \mathrm{mg} / \mathrm{ml}$ adenovirus add dropwise $8 \mu \mathrm{l}$ of $0.5 \mathrm{mg} / \mathrm{ml}$ texas red (diluted from $5 \mathrm{mg} / \mathrm{ml}$ stock with dialysis buffer immediately before use). Incubate for 1 hour in the dark on a rocker at room temperature.

4. To block excess texas red dye, add $40 \mu$ of freshly made $1.5 \mathrm{M}$ hydroxylamine $\mathrm{pH} 8.5$ and incubate for another hour as described in step 3. .

5. Repurify virus on $\mathrm{CsCl}$ step gradient as described in section 3.1.1., steps 7 and 10.

6. Determine protein concentration using Micro BCA assay (Pierce) and freeze virus in aliquots of 0.4 $\mathrm{mg} / \mathrm{ml}$.

\subsubsection{Cold-synchronized virus entry into cells}

1. Two days before infection, seed HeLa cells (or any other cell line) on round glass coverslips in DMEM growth medium placed in a 24 well dish. At the day of infection cells should be 60 to $90 \%$ confluent.

2. Transfer 24 well dish to an aluminum plate coated with a wet kim wipe and kept on ice. Wash cells once with cold binding medium (RPMI-0.2\% BSA, 15 mM Hepes-NaOH, pH 7.4).

3. Dilute stock texas-red labeled virus (typically $0.2 \mu \mathrm{l}$ of $0.26 \mathrm{mg} / \mathrm{ml}$ per coverslip, approximately 
1'000 virus particles per cell) into cold binding medium and add $0.2 \mathrm{ml}$ of this dilution to each coverslip.

4. Bind virus to the cell surface in the cold on a gently rocking platform for $90 \mathrm{~min}$.

5. Wash off unbound virus with cold binding medium and briefly add $0.5 \mathrm{ml}$ of warm internalization medium (DMEM-0.2\% BSA) to each coverslip. Remove medium and add fresh $0.5 \mathrm{ml}$ of warm DMEM-0.2\% BSA. Incubate for a given time in a $37^{\circ} \mathrm{C} \mathrm{CO}_{2}$ incubator.

6. Wash cells quickly in PBS at room temperature and fix immediately in $3.3 \%$ para-formaldehyde for $15 \mathrm{~min}$ at room temperature.

7. Quench unreacted para-formaldehyde with $50 \mathrm{mM} \mathrm{NH}_{4} \mathrm{Cl}$ in $\mathrm{PBS}$ for $5 \mathrm{~min}$ at room temperature and wash briefly with PBS.

8. Mount slide in PBS containing DABCO and seal edges of coverslip with nailpolish.

9. For best results analyze within 24 hours.

\subsubsection{Quantification of particles}

1. Record a digital picture of a group of 2 to 4 cells with a CCD camera in DIC mode using a $40 \mathrm{x}$ objective across the middle of the cells (examples see Fig. 2 a, c, e).

2. Transfer image as a TIFF file on-line to the hard disk of a personal computer. 
3. Record the corresponding fluorescence picture using the texas red or fluorescein filter set at maximal intensity settings integrating a total of 50 frames (examples see Fig. 2 b, d, f).

\section{Repeat step 2..}

5. Open the recorded TIFF file of the DIC image in the NIH image program.

6. Outline the cells and nuclei in plain white color using the "pencil" tool.

7. Set threshold such that only the white outlines are visible. Make image binary. Select all.

8. Load Macro “image_registration".

9. Open the corresponding fluorescence image and enhance contrast using the built in automatic software function under the "Process" menu.

10. Under "Special", "define image to register" and the DIC outline image to "register".

11. Use the "Blend" and "Divide" commands to merge the images.

12. Define the "Density Slice" such that all the fluorescent particles become colored and are selected. Save image.

13. Outline the area of interest (nucleus or whole cell) using the "free hand" mode and determine the number of fluorescent particles by the "Analyze Particles" function. 
14. Import data into a statistics program (e.g., Microsoft's Excel or Adelbeck's KaleidaGraph) for further analysis and data presentation (example see Fig. 3).

15. Process TIFF files and arrange with Adobe Photoshop software program for printing, e.g., on a Fuji Pictography 3000 sublimation printer.

As can be seen in Figure 2, virus bound to the cell surface of HeLa cells in the cold is more or less evenly distributed over the cell. The ratio of virus particles over the nucleus compared to the cytoplasm (Nuc/Cyt) is about 0.29 (Fig. 3). After $10 \mathrm{~min}$ of virus internalization at $37^{\circ} \mathrm{C}$, a qualitatively similar result is obtained, with a nuclear to cytoplasmic ratio of fluorescent viruses approximating about 0.32 . After 60 min of internalization, a different picture emerges. The majority of viruses has now moved towards the nucleus. The nuclear to cytoplasmic distribution coefficient at $60 \mathrm{~min}$ of warming cells is about 1.28 (Fig. 3).

It is important to note that by conventional fluorescence microscopy it is not possible to determine how close to the nuclear membrane the virus particles in fact are. Confocal microscopy and thin section electron microscopy have been applied to resolve this question. The results will presented elsewhere demonstrating that the fluorescently-labeled viruses enter the cells and localize to nuclear pore complexes with similar efficiencies as unlabeled control virus (Greber et al. submitted). No aggregated viruses inside or outside the cells are detected by electron microscopy suggesting that each fluorescent dot represents a single virus particle. Thus, the method described here truely measures virus transport from the cell surface or endosomes across the cytoplasm towards the nucleus. 


\section{NOTES}

1. Typical yields of virus vary from cell to cell and of course depend on the number of cells on the dish. We found that ten $100 \mathrm{~mm}$ dishes of $\mathrm{KB}$ cells (approximately $4 \times 10^{7}$ cells) yield about $1 \mathrm{mg}$ virus.

2. Freon helps dissociating aggregated virions during virus extraction from the cells. To prevent virus aggregation after cell lysis, it is important not to overload the $\mathrm{CsCl}$ gradients. One SW50 tube should not contain more than $0.5 \mathrm{mg}$ of virus. For long term storage, a concentration of $2 \mathrm{mg} / \mathrm{ml}$ virus should not be exceeded.

3. Check $\mathrm{pH}$ of the silicotungstic acid stock solution each time before use (pH will drop with time).

4. If the adenovirus preparation is contaminated with AAV, at least one strong band of AAV protein 3 (VP-3) shows up below the adenovirus IIIa/fiber bands in SDS-PAGE (data not shown, see also 25). AAV proteins 1 and 2 (VP-1 and VP-2) are less abundant than VP-3 and stain weakly in Coomassie blue.

5. Texas-red labeled virus prepared under these conditions contains maximally 2.4 molecules of texas red per hexon monomer. Texas red labeled virus has the same specific infectivity (per protein) as unlabeled virus as determined by plaque assay. This virus preparation remains active for months.

6. Fluorescein isothiocyanate (FITC) labeled adenovirus can be prepared using a similar protocol. Virus is dialyzed against $0.01 \mathrm{M}$ sodium bicarbonate containing $0.14 \mathrm{M} \mathrm{NaCl}, 1 \mathrm{mM} \mathrm{MgCl}$, for 2 hours and protein concentration is determined using Micro BCA assay (Pierce). The $\mathrm{pH}$ of the virus solution is adjusted to 9 by adding $1 / 5$ of the volume $0.5 \mathrm{M}$ sodium carbonate buffer, $\mathrm{pH} 9.0$. Labeling is initiated by adding $16 \mu \mathrm{l}$ of $0.5 \mathrm{mg} / \mathrm{ml}$ FITC solution (diluted immediately before use into $0.1 \mathrm{M}$ sodium carbonate buffer, $\mathrm{pH} 9$ from a $5 \mathrm{mg} / \mathrm{ml}$ stock solution made in DMSO) to $125 \mu \mathrm{l}$ of $1.8 \mathrm{mg} / \mathrm{ml}$ virus suspension. Incubate for one hour in the dark on a rocker at room temperature. Treat with hydroxylamine and repurify virus on $\mathrm{CsCl}$ gradient as described above. Analysis of FITC labeled virus by SDS-PAGE and fluoroimaging indicated that $47 \%$ of the label is 
incorporated into hexon, $13 \%$ into penton base, $18 \%$ into protein IIIa and fiber, $3 \%$ into protein VI, $7 \%$ into protein VII and $12 \%$ into protein IX (Fig. 1, lane 2).

7. PBS containing $0.1 \%$ sodium azide can be used instead of PBS to minimize bacterial contamination.

8. DABCO-containing mounting media only lasts a few weeks and should be made fresh on a regular basis. An alternative mounting medium is based on NPGT (N-Propyl-gallate-Glycerol-Tris). For $25 \mathrm{ml}$, mix $17.5 \mathrm{ml}$ glycerol (87\%), 7.5 ml 0.1 M Tris-HCl pH 9.5, 2.5 g N-propyl-gallate in a 50 $\mathrm{ml}$ screw cap plastic tube. Place tube into water bath sonicator (e.g., Branson Model 1210) and sonicate for $15 \mathrm{~min}$ at $37^{\circ} \mathrm{C}$. Transfer solution into vacuum flask and degas extensively under house vacuum. Store aliquots at $-20^{\circ} \mathrm{C}$. NPGT medium is recommended for texas red- or rhodamine-labeled probes, but appears to quench fluorescein-labeled probes.

9. A third mounting medium consists of $80 \%$ glycerol, $20 \mathrm{mM}$ Tris- $\mathrm{HCl}, \mathrm{pH} 8.8,0.5 \%$ Paraphenylene-diamine (Sigma). This medium has a slightly brownish color and lasts several months if stored at $-20^{\circ} \mathrm{C}$. It works equally well with both, Texas red and FITC probes.

\section{ACKNOWLEDGEMENTS}

We thank Dr. Robert Stidwill for help with image aquisition and analysis and comments to the manuscript. This work was supported by the Swiss National Science Foundation (grant no. 3143’412.95 to UFG) and the Kanton of Zürich. 


\section{FIGURES}

Fig. 1: SDS 10-15\% polyacrylamide gel electrophoresis (PAGE) of FITC-labeled adenovirus type 2. 8 $\mu \mathrm{g}$ of FITC-labeled virus was denatured in SDS-sample buffer at $95^{\circ} \mathrm{C}$ for 3 min and fractionated by SDS-PAGE. FITC-containing protein bands were immediately analyzed on a fluoroimager Model 575 (Molecular Dynamics) at $488 \mathrm{~nm}$ excitation wave length using the 530 DF30 band pass emission filter (Fluorogram). The relative fluorescence intensities of each protein band were determined by the ImageQuant software (Molecular Dynamics). Results are expressed as \% of total FITC labeling (n.d. not detected). The gel was then stained with $0.1 \%$ Coomassie brilliant blue in $20 \%$ methanol, $5 \%$ acetic acid and digitized by a UTA-IE scanner (UMAX Data System Inc, Taiwan, R.o.C.). The result is shown on the right side (Coomassie).

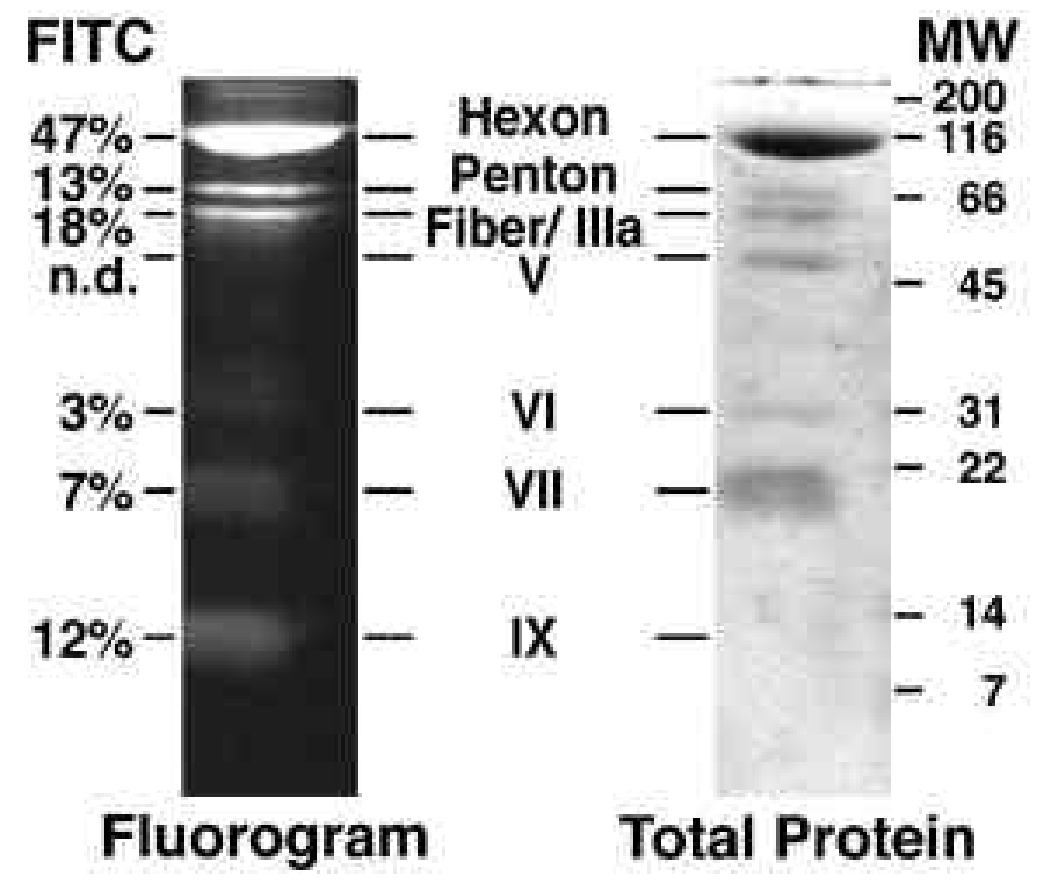


Fig. 2: Entry of texas-red labeled adenovirus into HeLa cells. Virus was bound to the cell surface in the cold for $90 \mathrm{~min}(\mathrm{a}, \mathrm{b})$ and internalized for $10 \mathrm{~min}(\mathrm{c}, \mathrm{d})$ or $60 \mathrm{~min}$ at $37^{\circ} \mathrm{C}(\mathrm{e}, \mathrm{f})$. Nomarski DIC optics was used to visualize the cells (Nom). Virus was detected by fluorescence microscopy using the Texas red filter set (Ad-tx red). The focus of the microscope objective was set to the middle of the cells. The apparent depth of field was estimated to be in the order of several $\mu \mathrm{m}$ (see also 26).

Outlines of cells and nuclei in Figures b, d, f were generated with the NIH image software program.

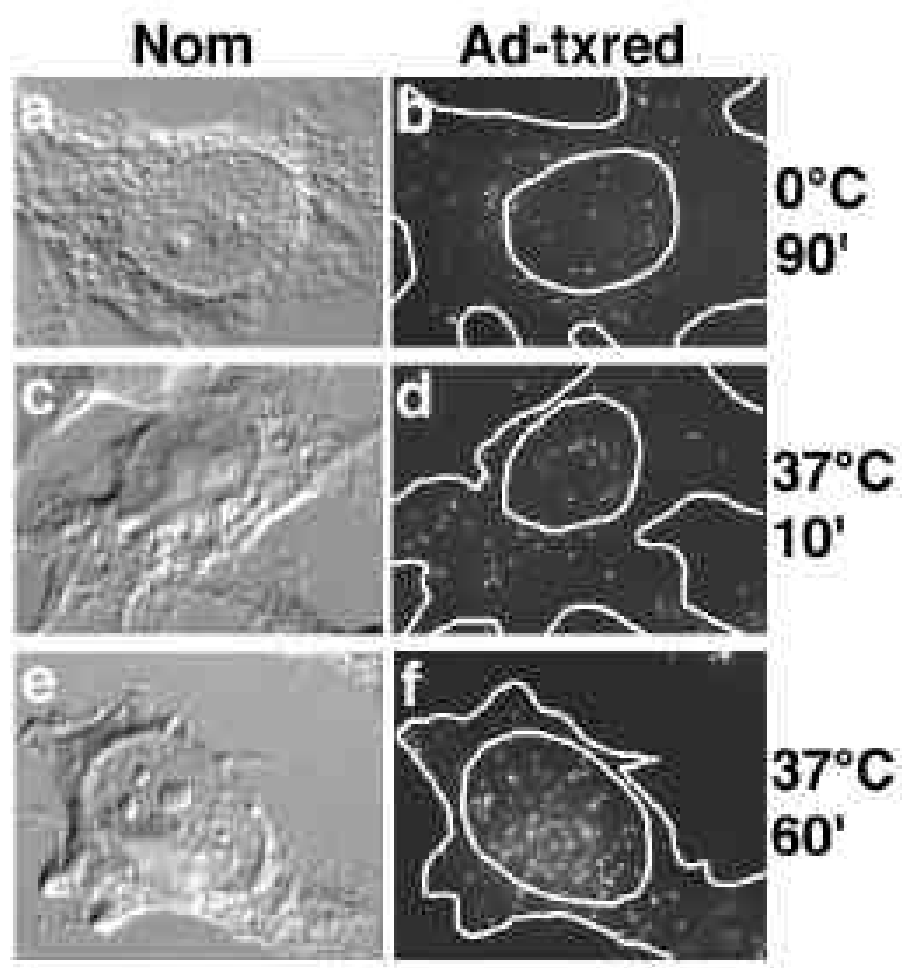


Fig. 3: Summarized data of cell entry of texas red-labeled adenovirus particles. Images, as presented in Fig. 2, were analyzed for subcellular localization of fluorescent virus particles. Results are expressed as the mean ratio of nuclear to cytoplasmic viruses (Nuc/Cyt Ad). Standard deviations are indicated by error bars including the number of cells analyzed for each experiment (n).

Fig. 3: Transport of adenovirus to the nucleus

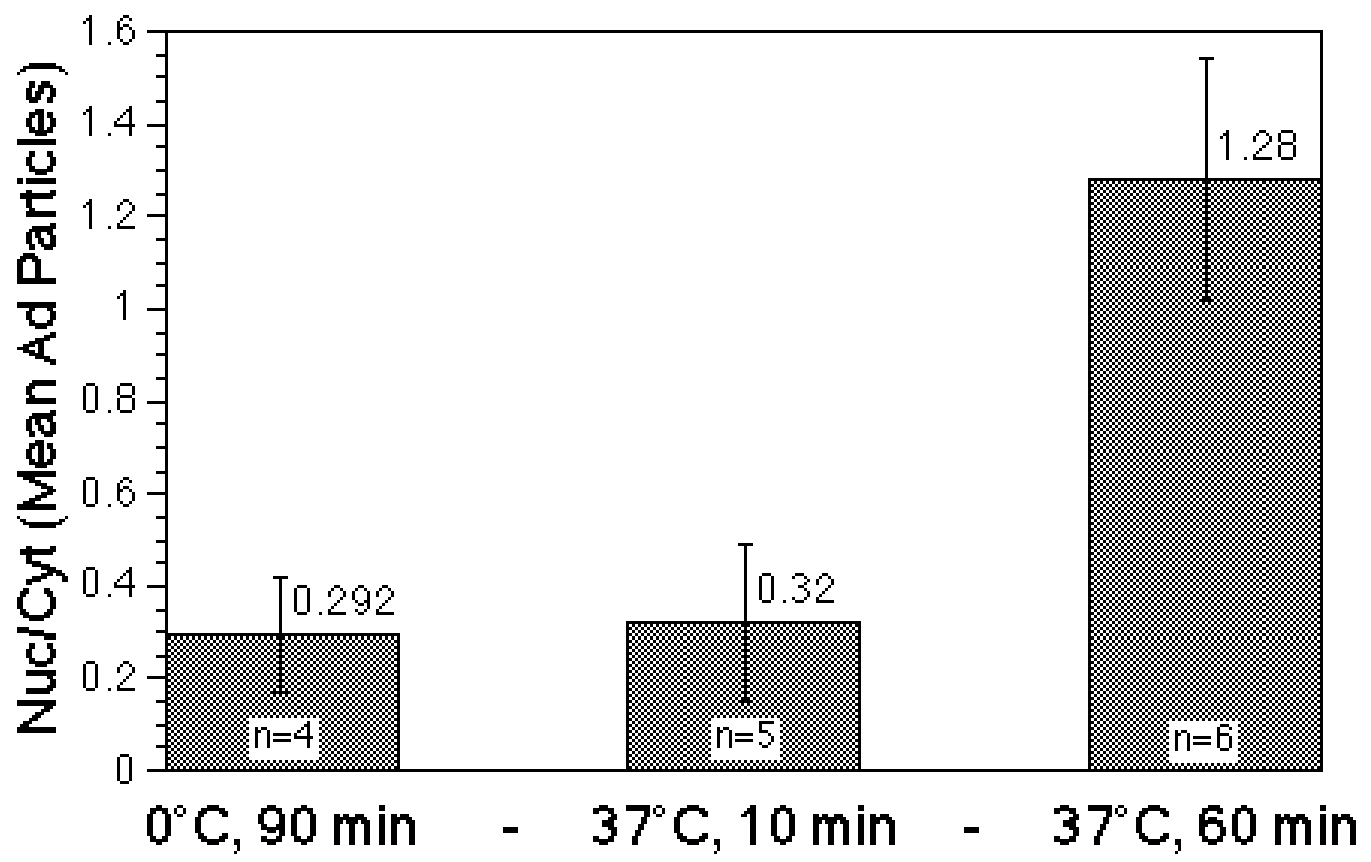


Adenovirus methods and protocols, in Meth. Mol. Med. Vol 21, 217-230, Humana Press, Inc, ed Wold, W.S.M.

\section{REFERENCES}

(1). Mulligan, R. C. (1993) Science 260, 926-932.

(2). Trapnell, B. C., and Gorziglia, M. (1995) Curr. Op. Biotech. 5, 617-625.

(3). Hanania, E. G., Kavanagh, J., Hortobagyi, G., Giles, R. E., Champlin, R., and Deisseroth, A. B. (1995) American Journal of Medicine 99, 537-552.

(4). Rosenfeld, M. A., and Collins, F. S. (1996) Chest 109, 241-252.

(5). Crystal, R. G. (1995) Science 270, 404-410.

(6). Horwitz, M. S. (1990) in Adenoviridae and their replication, eds. B. N. Fields and D. M. Knipe (Raven Press, New York), Vol. 1, pp. 1679-1721.

(7). Stewart, P. L., Fuller, S. D., and Burnett, R. M. (1993) EMBO J. 12, 2589-2599.

(8). Greber, U. F., Willetts, M., Webster, P., and Helenius, A. (1993) Cell 75, 477-486.

(9). Bergelson, J. M., Cunningham, J. A., Droguett, G., Kurt-Jones, E. A., Krithivas, A., Hong, J. S., Horwitz, M. S., Crowell, R. L., and Finberg, R. W. (1997) Science 275, 1320-1323.

(10). Tomko, R. P., Xu, R., and Philipson, L. (1997) Proc. Natl. Acad. Sci. USA 94, 3352-3356.

(11). Hong, S. S., Karayan, L., Tournier, J., Curiel, D. T., and Boulanger, P. A. (1997) EMBO J. 16, 2294-2306.

(12). Huang, S., Kamata, T., Takada, Y., Ruggeri, Z. M., and Nemerow, G. R. (1996) Journal of Virology 70, $4502-4508$. 
Adenovirus methods and protocols, in Meth. Mol. Med. Vol 21, 217-230, Humana Press, Inc, ed Wold, W.S.M.

(13). Wickham, T. J., Mathias, P., Cheresh, D. A., and Nemerow, G. R. (1993) Cell 73, 309-319.

(14). Greber, U. F., and Kasamatsu, H. (1996) Trends Cell Biol. 6, 189-195.

(15). Wickham, T. J., Filardo, E. J., Cheresh, D. A., and Nemerow, G. R. (1994) J. Cell Biol. 127, 257-264.

(16). Pastan, I., Seth, P., FitzGerald, D., and M., W. (1986). Adenovirus entry into cells: some new observations on an old problem, A. L. Notkins and M. B. A. Oldstone, eds. (New York: Springer Verlag), pp 141-146.

(17). Greber, U. F., Webster, P., Weber, J., and Helenius, A. (1996) EMBO J. 15, 1766-1777.

(18). Görlich, D., and Mattaj, I. W. (1996) Science 271, 1513-1518.

(19). Harlow, E., and Lane, D. (1988). Antibodies, a laboratory manual, E. L. Harlow, D., ed.: Cold Spring Harbor Laboratories).

(20). Nevins, J. R. (1981) Methods Enzymology 65, 768-785.

(21). Maizel, J. V. J., White, D. O., and Scharff, M. D. (1968) Virology 36, 115-126.

(22). Chardonnet, Y., and Dales, S. (1970) Virol. 40, 462-477.

(23). Ginsberg, H. S. (1984). The adenoviruses (New York: Plenum Press).

(24). Laemmli, U. K. (1970) Nature 227, 680-685.

(25). Berns, K. I. (1996) in Parvoviridae: the viruses and their replication, eds. B. N. Fields, D. M. Knipe and P. M. Howley (Raven Press, Philadelphia), pp. 1017-1041.

(26). Lacey, A. J. (1991) in The principles and aims of light microscopy, ed. A. J. Lacey (Oxford University Press, Oxford, England), pp. 1-59. 